\title{
School Culture and School Effectiveness: The Mediating Effect of Teachers' Job Satisfaction
}

\author{
Xiaoju Duan \\ Aalborg University, Aalborg 9000, Denmark \\ Business Academy Southwest, Esbjerg 6700, Denmark \\ Xiangyun Du \\ Aalborg University, Aalborg 9000, Denmark \\ Qatar University, Doha, Qatar \\ Kai Yu \\ Beijing Normal University, \\ Beijing 100875, China
}

\begin{abstract}
This study has investigated the relationship among school culture, teachers' job satisfaction, and school effectiveness. It also explored the mediating effect of teachers' job satisfaction on school culture and school effectiveness. Participants of the study include1, 297 teachers from 6 lower secondary and upper secondary schools in Beijing, China. Quantitative methods were used for data generation, consisting of 3 questionnaire-based surveys to measure, separately, school culture, school effectiveness, and job satisfaction from the teachers' perspective. The results indicated positively significant relationships among school culture, teachers' job satisfaction, and school effectiveness and that teachers' job satisfaction partially mediated the impact of school culture on school effectiveness. In light of these results, limitations and directions for future research are provided, as well as implications for education.
\end{abstract}

Keywords: school culture; school effectiveness; effects; teachers' job satisfaction.

\section{Introduction}

Education has great importance in the development of individuals and countries. Thus, education has been highly valued in modern societies. The quality of the education provided in schools is normally evaluated based on measures of school performance and school effectiveness. Improving school effectiveness, a fundamental aim for school teachers, leaders, and societies, could be affected by a number of factors, for instance school culture (Badri, et al., 2014; Bhengu \& Mthembu, 2014; Scheerens, Witziers \& Steen, 2013; Vadi, 2007) 
and teachers' job satisfaction (Hosseinkhanzadeh, Hosseinkhanzadeh \& Yeganeh, 2013; Michaelowa, 2002; Somech, Drach-Zahavy \& Anat, 2000; Treputtharat \& Tayiam, 2014), among others.

The term of school culture is often referred to organizational culture positioned in the educational background (Schoen \& Teddlie, 2008) which constitutes the primary assumptions, convention and principles shared by school members (Maslowski, 2001). School culture is critical because it displays habits, traditions and formalities (Stoll, 1999) and it shapes teacher-student interacts as well as interacts among teachers (Powers, 2009).

Job satisfaction is one of the main fields of study in social psychology and the sociology of organizations. Job satisfaction refers to workers' positive and negative feelings and their behaviour in the organizational environment (Sanjeewani, 2011). Teachers' job satisfaction often refers to both external and internal satisfaction (Chaaban \& Du, 2017).

Existing literature has reported that both school culture and teachers' job satisfaction are closely related to school effectiveness (Ali, Sharma \& Zaman, 2017; Somech, Drach-Zahavy \& Anat, 2000). It has also been shown that school culture influences teachers' job satisfaction (Aldridge \& Fraser, 2016; Malinen \& Savolainen, 2016; Skaalvik \& Skaalvik, 2017). Thus, school culture, teachers' job satisfaction, and school effectiveness can be assumed to be interrelated, though there is little known about the precise relationship among them. Therefore, this study aims to investigate the relationship among school culture, teachers' job satisfaction, and school effectiveness, with the formulated research question of whether teachers' job satisfaction plays a mediating role in teachers' perceptions of school culture and school effectiveness.

\section{Literature review}

Previous studies are reviewed and presented by the relationships between school culture and school effectiveness, School culture and teachers' job satisfaction, Teachers' job satisfaction and school effectiveness.

\section{School culture and school effectiveness}

Previous studies have shown that organizational culture has a substantial influence on workers' and organizations' work results. This also holds true in an educational context because school culture can influence students' academic achievement (Badri et al., 2014). One study investigated the relationships between school culture evaluation and actual school performance in 60 Estonian secondary schools where school administrators, teachers and supporting staff were interviewed. Estimates of school culture were measured by an organizational culture questionnaire and school performance was measured based on national examination results. The study found that organizational culture could affect the performance of schools (Vadi, 2007). In another study, a meta-analysis of 155 researches on school effectiveness from 1984 to 2005 was conducted. After examining 1,211 associations between school effectivenessenhancing factors and variables on student outcomes, an orderly school 
environment was found to affect students' achievement (Scheerens, Witziers \& Steen, 2013).

The influence of school culture on school effectiveness has also been found in studies concerning school leadership. One study found out that the reason of why two "sister" schools were so different in terms of learner achievement, was that the two principals employed two dramatically different leadership approaches. Furthermore, those two different leadership approaches shapes and maintains distinct school cultures (Bhengu \& Mthembu, 2014). Finally, a study on elementary schools showed that principals could indirectly affect school effectiveness by influencing the school's culture (Hallinger, Bickman \& Davis, 1996).

\section{School culture and teachers' job satisfaction}

It has been shown that organizational culture influences employee's job satisfaction in addition to its effect on organizational effectiveness (Morris \& Bloom, 2002). In cases where the employer is more concerned with employees' motivational or emotional needs while highlighting their skills and knowledge, these employees are more likely to report higher job satisfaction levels (Hanson \& Miller, 2002). Similarly, school culture has been shown to be a relatively strong and consistently predictive factor among the many factors influencing the degree to which teachers are happy with their jobs (Treputtharat \& Tayiam, 2014).

Ma and MacMillan (1999) put forward a definition of organizational culture as collegiality, or the extent to which teachers considered both themselves and other teachers to be sharing general and specific attitudes regarding how children learn. In doing so, they discovered that organizational culture plays a key role in predicting the level of satisfaction felt by teachers. Furthermore, a study investigating the job satisfaction of 329 teachers in Thailand showed that this could be predicted by school culture, with a multiple correlation co-efficient of 0.84 and a predictive power of teacher job satisfaction of $72.1 \%$ (Treputtharat \& Tayiam, 2014).

The relationship between organizational culture and job satisfaction was further examined in a study on 123 middle school teachers in Tehran during the 2009 school year, where by cluster sampling was used to select the schools. In this case, the used research tools were the Darabi Organizational Culture Questionnaire and the Smith, Kandle, and Heulin Job Descriptive Index. The data analysis showed that the relationship between organizational culture and job satisfaction was significant (Hosseinkhanzadeh et al., 2013).

\section{Teachers' job satisfaction and school effectiveness}

Job satisfaction plays a key role in the success of an organization's business, whereby the relationship between job satisfaction and work performance has been shown to be significant (Usop, Kadtong \& Usop, 2013), and high employee job satisfaction is important in order for an organization to function and achieve its goals. In a similar manner, in an educational context the job satisfaction experienced byteachers is likewise crucial for schools' successful operation. Job satisfaction has been found to have a positive and significant effect on teaching efficacy (Collie, Shapka \& Perry, 2012), student learning (Michaelowa, 2002), 
student academic performance (Hosseinkhanzadeh et al., 2013), and school effectiveness (Somech et al., 2000).

For instance, Horn-Turpin (2009) investigated the job satisfaction levels of 121 teachers from special education and showed that this was positively correlated with their perceived teaching efficacy. Here, how satisfied the teachers were with their performance in the school, the more likely their practice wassuccessful, and, therefore, the more likely the academic progress and achievement of their students met the educational targets (Treputtharat \& Tayiam, 2014). However, those teachers who were not satisfied, due to some factors, as a lack of career advancement opportunities, low motivation, low salary, or ineffective communication with leaders, were more likely to leave the school. Such high rates of teacher turnover led to less successful outcomes with regard to school effectiveness as well as issues with students, such as emotional instability and poor learning behaviour (Khawary \& Ali, 2015).

To sum up, the literature ranging across a number of different educational fields strongly suggests the presence of positive and complex relationships between the concepts of school culture and teacher job satisfaction as well as school effectiveness. One study even determined that the relationship between the school climate and teachers' depersonalization and emotional exhaustion was significantly mediated by the teachers' job satisfaction (Grayson \& Alvarez, 2008). Thus, it may be that school culture affects school effectiveness not just directly, but additionally via the influence of teachers' job satisfaction. In addition, through teaching practices, school organizational culture can also have an effect on student outcomes (Gamoran, Secada \& Marrett, 2000; Stearns, Banerjee, Mickelson \& Moller, 2014). In spite of the fact that a more positive school culture could directly influence school effectiveness, the actual teachers in that school may have different opinions of the school's culture. For example, those teachers experiencing less job satisfaction are likely to have more negative opinions of their teaching experience and of school traditions, which may also negatively affect overall school effectiveness. In all, it has been shown that teacher job satisfaction appears to have a mediating role between school culture and school effectiveness.

\section{Method}

Participants of this study, instruments, data analysis method are introduced in the following paragraphs.

\section{Participants}

The study was conducted in six primary and high schools in Beijing, China 2013. Participants include all teachers from these schools with 1,297 (96\%) valid respondents. The $4 \%$ of excluded responses were eliminated because they were incomplete. Of the participants included in the analysis, 1,067 were female $(82.3 \%), 221$ were male $(17.0 \%)$, and 9 questionnaires were missing gender data $(0.7 \%)$. This is due to the fact that the majority of school teachers are females in China. Of those surveyed, 1,154 responses were from teachers $(89.0 \%), 96$ were from employees in middle leadership positions (7.4\%), and 47 questionnaires were missing job title data (3.6\%).The participants in this study included 255 
teachers with less than six years of teaching experience (19.7\%), 432 teachers with six to fifteen years of teaching experience (33.3\%), 589 teachers with more than fifteen years of teaching experience $(45.4 \%)$, and 21 questionnaires missing teaching experience data $(1.6 \%)$.

\section{Instruments}

Three questionnaire-based surveys were used in this study. Survey one was a validated Chinese school version of the Denison Organizational Culture Survey (Duan, Du \& Yu, 2014). The Chinese school version evaluated four traits: involvement, consistency, adaptability and mission. Each trait consisted of three indexes and each index consisted of three items. Thus, survey one includes a total of 36 items that were taken as the index for school culture. An example of a questionnaire item is 'Everyone believes that they can have a positive impact'. Cronbach's alpha for this survey was 0.97 .

Survey two included five items that were defined by researchers in this study to measure school effectiveness, containing teaching quality, ethical education, leadership, values and parent satisfaction (Duan, Du \& Yu, 2014). An example of a questionnaire item from this survey is 'I think that the teaching quality has improved in recent years'. Cronbach's alpha was 0.92 .

Survey three included ten self-designed items for measuring teachers' satisfaction. These items addressed both internal and external satisfaction. An example of a questionnaire item is 'I am satisfied with the stability provided by my work'. Cronbach's alpha was 0.92 .

A five-point Likert-type scale was used for all items of the three surveys. Respondents were required to evaluate how much they agreed or disagreed with a statement. The scale was from 1 to 5 , with 1 being 'totally disagree' and 5 being 'totally agree'.

\section{Data analysis}

Descriptive analysis, internal consistency for survey and scales, correlations, and regressions were calculated by SPSS 15.0. Baron and Kenny's (1986) classical technique was applied to test the mediating hypothesis of teacher satisfaction on the relationship between school culture and effectiveness. As stated by Baron and Kenny (1986), several conditions should be fullfilled to establish the mediating effect: (1) the independent variable (school culture) is statistically related to the dependent variable (school effectiveness); (2) the independent variable (school culture) is significantly related with the mediating factor (teachers' satisfaction); (3) the mediating factor (teachers' satisfaction) is significantly related with the dependent variable (school effectiveness); and (4) the independent variable (school culture) affects less on the dependent variable (school effectiveness) when the mediator (teachers' satisfaction) was added to the model, the mediating effect is partial. If the effect of independent variable (school culture) on the dependent variable (school effectiveness) disappears when the mediator is introduced to the model, the mediating effect is full.

All the continuous variables were centralized to avoid multicollinearity before regression analyses were performed. 


\section{Results}

Descriptive data and the results of mediating effect are shown in the following parts.

\section{Descriptive data}

Descriptive statistics and correlations among school culture, school effectiveness, and teachers' satisfaction are reported in Table 1. Results showed that school culture, school effectiveness, and teachers' satisfaction were positively correlated with each other $(\mathrm{ps}<0.01)$.

Table 1. Descriptive statistics and correlations among school culture, school effectiveness, and teachers' satisfaction

\begin{tabular}{lcccccc}
\hline & \multicolumn{3}{c}{ Descriptive statistics } & \multicolumn{3}{c}{ Correlation } \\
& Min & Max & Mean & SD & $\begin{array}{l}\text { School } \\
\text { culture }\end{array}$ & $\begin{array}{l}\text { School } \\
\text { effectiveness }\end{array}$ \\
\hline School culture & 1.78 & 5.00 & 4.39 & 0.59 & & \\
School effectiveness & 1.60 & 5.00 & 4.46 & 0.68 & 0.90 & \\
Teachers' satisfaction & 1.30 & 5.00 & 4.08 & 0.76 & 0.83 & 0.80 \\
\hline
\end{tabular}

\section{Mediating effect}

As presented in Table 2, school culture and school effectiveness were positively correlated $(\beta=0.901, P<0.001)$. Teachers' satisfaction was positively coupled with school culture $(\beta=0.831, P<0.001)$. Teachers' satisfaction showed a mediating effect on the relationship between school culture and school effectiveness, on account of the fact that the regression coefficient for school culture dropped when teachers' satisfaction was inserted (from $\beta=0.901$ to $\beta=0.756$ ). The mediating effect was found to be only partial because the coefficient for school culture was still significant when the mediator was added.

Table 2. Regression analysis results

\begin{tabular}{lllllll}
\hline & $\mathrm{R}$ & $\mathrm{R}$ Square & Standardized Coefficients Beta & $\mathrm{t}$ & Sig \\
\hline Model 1 & & & & & & \\
$\mathrm{C}$ & 0.091 & 0.812 & 0.901 & 77.975 & $<0.001$ \\
Model 2 & & & & & \\
A & 0.831 & 0.691 & 0.831 & 56.124 & $<0.001$ \\
Model 3 & & & & & \\
$\mathrm{C}^{\prime}$ & 0.906 & 0.821 & 0.756 & 37.292 & $<0.001$ \\
$\mathrm{~B}$ & & & 0.174 & 8.591 & $<0.001$ \\
\hline
\end{tabular}

The mediating effect was $0.160($ effectm $=\mathrm{ab} / \mathrm{c})$. The mediating effect can explain $9.5 \%$ of the dependent variables' variation $($ sqrt $(0.821-0.812)=0.095)$.

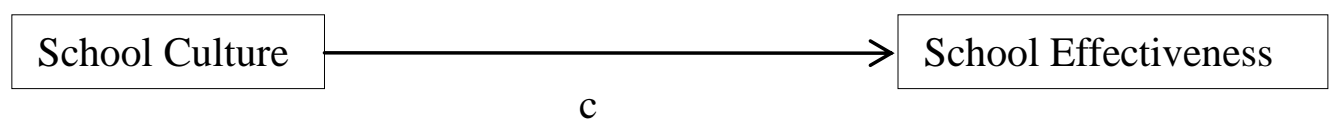

Model 1. The relationship between school culture and school effectiveness 


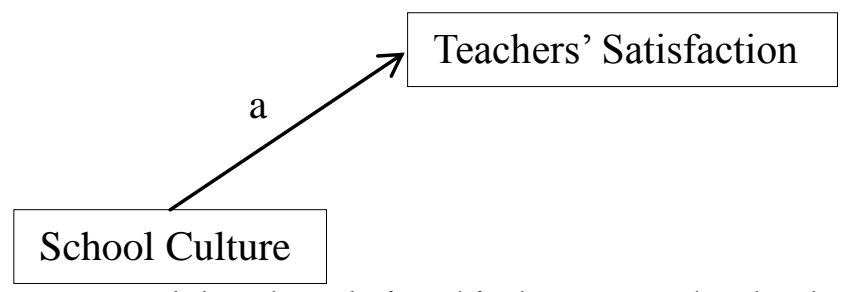

Model 2.The relationship between school culture and teachers' satisfaction

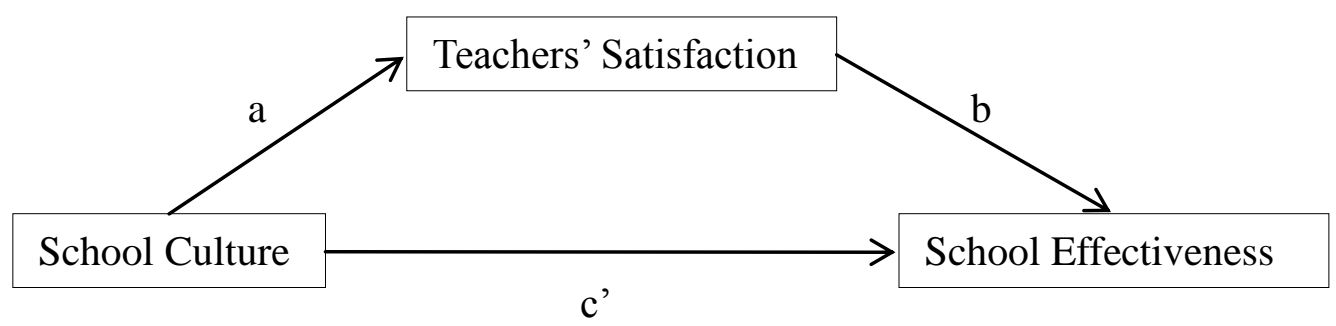

Model 3. The mediating effect of teachers' satisfaction on the relationship between school culture and school effectiveness

\section{Discussion}

This study has examined the relationship among school culture, teachers' job satisfaction, and school effectiveness. The mediating role of teachers' job satisfaction was also studied. The results from correlations demonstrated that these three factors are positively correlated with each other. The regression analysis demonstrated that teachers' job satisfaction played a mediating role on the relation between school culture and school effectiveness. Furthermore, the mediating effect was partial.

The relationship among school culture, teachers' job satisfaction and school effectiveness

The finding that school culture, teachers' job satisfaction and school effectiveness are correlated with each other is in line with previous studies. This study has demonstrated that school culture, as the representation of the collective relationships, ceremonies, and rituals within a school, is an integral indicator of the effectiveness of a school (Treputtharat \& Tayiam, 2014). This result is further supported by Hongboontri and Keawkhong's 2014 qualitative study, which detailed the influences of school culture on teachers' work practices. This finding is also consistent with a meta-analysis study from the organizational field (Hartnell, Ou \& Kinicki, 2011).

Concerning the close relationship between school culture and teachers' job satisfaction, some studies show that a good organizational culture is crucial to the enhancement of workers' job satisfaction (Hosseinkhanzadeh et al., 2013). Improving school culture may increase teachers' motivation and reduce the risks of stress and depression for teachers (Ferguson, Frost \& Hall, 2012). A supportive and motivating school culture makes teachers feel more competent and more satisfied with their schools and work (Usop et al., 2013).

The results of this study have shown that teachers' job satisfaction was correlated with school effectiveness, which was in line with the conclusions of a review study (Judge et al., 2001). Aziri (2011) concluded that job satisfaction has a significant effect on the level of workers' motivation, while workers' 
motivation has an effect on productivity, and therefore also on an organization's performance. Thus, when employees are satisfied with their jobs, this satisfaction leads to higher productivity at the organizational level. Accordingly, research shows that teachers who are satisfied with their work are more effective (Horn-Turpin, 2009; Treputtharat \& Tayiam, 2014).

\section{The mediating effect}

Teachers play an essential role in all school activities. In fact, school's culture cannot affect school outcomes directly. The influence need go through teachers' practice (Gamoran et al., 2000; Stearns et al., 2014). Teachers play a substantial part in generating, transforming and diffusing school culture. While education directors and school leaders are normally in charge of creating cultural norms in school environment, teachers must agree with and facilitate these principles (Kruse \& Louis, 2009; Stearns et al., 2014). This finding demonstrates that teachers' job satisfaction is important in the relationship between school culture and school effectiveness, which is consistent with Grayson's (2008) study, which found that teacher job satisfaction mediated the impact of school culture on teachers' emotional conditions.

The survey results show significant differences among schools concerning school culture. Some schools scored significantly better on one or more of the four school culture traits, namely, involvement, consistency, adaptability and mission. These high-scoring schools may have supportive leadership, high rates of engagement among school members, consistent rules and purpose, higher adaptability to new situations, and a clear mission for students and society. Teachers in these schools reported feeling cared for, trusted and needed; in other words, they feel more satisfied with their jobs. They also reported being more willing to be responsible for school routines and students' instruction. As a result, students are likely to be more engaged in these schools and their learning achievement levels can be expected to be higher (Lee \& Smith, 1996). Results of the current study indicate that schools with stronger cultures have more satisfied teachers, higher school effectiveness, and vice versa.

Although teachers' job satisfaction mediated the influence of school culture on school effectiveness, this mediating effect is partial, explaining $9.5 \%$ of the dependent variables' variation. For the most part, school culture influenced directly on school effectiveness.

\section{Limitations of the research}

This study is limited in several ways. First, as this study was carried out in Beijing municipality, China, the relevance of the results may be limited to this particular context, and there may be differences regarding school culture elsewhere in China and other countries (Zhu, Devos \& Tondeur, 2014). Thus, the generalizability of the current study may be limited. Second, while the present study was cross-sectional, there is the possibility of a bi-directional relationship among the factors studied, predicting that school culture may influence the teachers' satisfaction, and at the same time, all the teachers contribute to shaping the school culture. Higher level of teacher satisfaction leads to better job performance, which in turn, has a positive impact on job satisfaction. This bidirectional relationship has not been the focus of the current study, but deserves 
attention for future research. Third, the present study took school culture as one entity; future studies may investigate its traits or indexes separately to explore how each trait or index affects these relationships.

\section{Directions for future research}

As the limitation of this study indicates, further studies may consider three directions. The relationship among school culture, teachers' job satisfaction and school effectiveness, and the mediating effect of teachers' job satisfaction need be tested in other cultures. Longitudinal designs are needed to more precisely understand the nature of the bi-directional relationship. Additional directions for research include other factors that can explain these relationships, such as leadership and teachers' emotional state.

\section{Conclusion}

The current investigation identified a significantly positive relationship among school culture, teachers' job satisfaction and school effectiveness. The results also demonstrated that teachers' job satisfaction served as a mediator to the relationship between school culture school effectiveness.

The present study demonstrated the dynamic relationships among school culture, teachers' job satisfaction and school effectiveness. These three factors need be considered as interactive and supportive with each other. It was suggested that teachers' job satisfaction should be paid more attention when improving school effectiveness.

\section{References}

Aldridge, J. M. \& Fraser, B. J. (2016). Teachers' views of their school climate and its relationship with teacher self-efficacy and job satisfaction. Learning Environments Research, 19(2), 291-307. Retrieved from https://doi.org/10.1007/s10984-015-9198-x

Ali, N. Sharma, S. \& Zaman, A. (2017). School culture and school effectiveness: Secondary schools in Pakistan. MOJEM: Malaysian Online Journal of Educational Management, 4(4), 50-65. Retrieved from https://doi.org/10.22452/mojem.vol4no4.4

Aziri, B. (2011). Job satisfaction: A literature review. Management Research and Practice, $3(4), 77-86$.

Badri, R., Amani-Saribaglou, J., Ahrari, G., Jahadi, N. \& Mahmoudi, H. (2014). School culture, basic psychological needs, intrinsic motivation and academic achievement: Testing a casual model. Mathematics Education Trends and Research, 2014, 1-13. Retrieved from https://doi.org/10.5899/2014/metr-00050

Baron, R. M. \& Kenny, D. A. (1986). The moderator-mediator variable distinction in social psychological research: Conceptual, strategic, and statistical considerations. Journal of Personality and Social Psychology, 51(6), 1173-1182. Retrieved from https://doi.org/10.1037//0022-3514.51.6.1173

Bhengu, T. T.\& Mthembu, T. T. (2014). Effective leadership, school culture and school effectiveness: A case study of two 'sister' schools in Umlazi Township. Journal of Social Sciences, 38(1), 43-52. Retrieved from https://doi.org/10.1080/09718923.2014.11893235

Chaaban, Y. \& Du, X. (2017). Novice teachers' job satisfaction and coping strategies: Overcoming contextual challenges at Qatari government schools. Teaching and Teacher Education,67, 340-350. Retrieved from https://doi.org/10.1016/j.tate.2017.07.002 
Collie, R. J., Shapka, J. D., \& Perry, N. E. (2012). School climate and social-emotional learning: Predicting teacher stress, job satisfaction, and teaching efficacy. Journal of educational psychology, 104(4), 1189. Retrieved from https://doi.org/10.1037/a0029356

Duan, X. J., Du, X. Y. \& Yu, K. (2014). The reliability and validity of the Chinese school version of the Denison Organizational Culture Survey. International Journal of Learning, Teaching and Educational Research, 9(1), 83-94.

Ferguson, K., Frost, L. \& Hall, D. (2012). Predicting teacher anxiety, depression, and job satisfaction. Journal of Teaching and Learning, 8(1), 27-42. Retrieved from https://doi.org/10.22329/jtl.v8i1.2896

Gamoran, A., Secada, W. G. \& Marrett, C. B. (2000). The organizational context of teaching and learning. In: Hallinan, M.T. (ed.), Handbook of the Sociology of Education. New York, Kluwer Academic/Plenum Publishers, pp. 37-63.

Grayson, J. L. \& Alvarez, H. K. (2008). School climate factors relating to teacher burnout: A mediator model. Teaching and Teacher Education, 24(5), 1349-1363. Retrieved from https://doi.org/10.1016/j.tate.2007.06.005

Hallinger, P., Bickman, L. \& Davis, K. (1996). School context, principal leadership, and student reading achievement. The Elementary School Journal, 96(5), 527-549. Retrieved from https://doi.org/10.1086/461843

Hanson, M. \& Miller, Jr., A. F. (2002). The productive use of strengths: Ashared responsibility. Industrial and Commercial Training, 34(1), 95-100. Retrieved from https://doi.org/10.1108/00197850210424935

Hartnell, C. A., Ou, A. Y. \& Kinicki, A. (2011). Organizational culture and organizational effectiveness: Ameta-analytic investigation of the competing values framework's theoretical suppositions. Journal of Applied Psychology, 96(4), 677-694. Retrieved from https://doi.org/10.1037/a0021987.supp

Hongboontri, C. \& Keawkhong, N. (2014). School culture: Teachers' beliefs, behaviors, and instructional practices. Australian Journal of Teacher Education, 39(5), 66-88. Retrieved from https:// doi.org/10.14221/ajte.2014v39n5.7

Horn-Turpin, F. D. (2009). A study examining the effects of transformational leadership behaviors on the factors of teaching efficacy, job satisfaction and organizational commitment as perceived by special education teachers. Doctoral dissertation. Virginia Polytechnic Institute and State University.

Hosseinkhanzadeh, A. A., Hosseinkhanzadeh, A. \& Yeganeh, T. (2013). Investigate relationship between job satisfaction and organizational culture among teachers. Procedia-Social and Behavioral Sciences, 84, 832-836. Retrieved from https://doi.org/10.1016/j.sbspro.2013.06.656

Judge, T. A., Thoresen, C. J., Bono, J. E. \& Patton, G. K. (2001). The job satisfaction-job performance relationship: A qualitative and quantitative review. Psychological Bulletin, 127(3), 376-407. Retrieved from https://doi.org/10.1037//00332909.127.3.376

Khawary, O. \& Ali, S. (2015). The causes and effects of English teachers' turnover: A case from Afghanistan. Improving Schools, 18(1): 20-34. Retrieved from https://doi.org/10.1177/1365480214566280

Kruse, S. D. \& Louis, K. S., (2009). Building strong school cultures: A guide to leading change. Thousand Oaks, CA, Corwin Press.

Lee, V. E. \& Smith, J. B. (1996). Collective responsibility for learning and its effects on gains in achievement for early secondary school students. American Journal of Education, 104, 103-147. Retrieved from https:// doi.org/10.1086/444122

Ma, X. MacMillan, R. B. (1999). Influences of workplace conditions on teachers' job satisfaction. The Journal of Educational Research, 92, 39-47. Retrieved from https://doi.org/10.1080/00220679909597627 
Malinen, O. P. \& Savolainen, H. (2016). The effect of perceived school climate and teacher efficacy in behavior management on job satisfaction and burnout: A longitudinal study. Teaching and Teacher Education, 60, 144-152. Retrieved from https://doi.org/10.1016/j.tate.2016.08.012

Maslowski, R. (2001). School culture and school performance: An explorative study into the organizational culture of secondary schools and their effects. Twente, University Press.

Michaelowa, K. (2002). Teacher job satisfaction, student achievement, and the cost of primary education in Francophone Sub-Saharan Africa (No. 188). HWWA Discussion Paper. Retrieved from https://doi.org/10.1353/jda.2008.0028

Morris, A. \& Bloom, J. R. (2002). Contextual factors affecting job satisfaction and organizational commitment in community mental health centers undergoing system changes in the financing of care. Mental Health Services Research, 4(2), 71-83.

Powers, J. M. (2009). Charter schools: From reform imagery to reform reality. New York, Palgrave Macmillan. Retrieved from https://doi.org/10.1057/9780230622111_1

Sanjeewani, H. H. V. M. (2011). Teachers, job satisfaction: A study of type 2 schools in polonnaruwa zone at Sri Lanka. Doctoral dissertation. Mahidol University.

Scheerens, J., Witziers, B. \& Steen, R. (2013). A meta-analysis of school effectiveness studies. Revista de Educacion, 2013(361), 619-645. Retrieved from https://doi.org/10.1080/13803611.2012.718485

Schoen, L. T. \& Teddlie, C. (2008). A new model of school culture: A response to a call for conceptual clarity. School Effectiveness and School Improvement, 19(2), 129-153. Retrieved from https://doi.org/10.1080/09243450802095278

Skaalvik, E. M. \& Skaalvik, S. (2017). Still motivated to teach? A study of school context variables, stress and job satisfaction among teachers in senior high school. Social Psychology of Education, 20(1), 15-37. Retrieved from https://doi.org/10.1007/s11218-016-9363-9

Somech, A. \& Drach-Zahavy, A. (2000). Understanding extra-role behavior in schools: The relationships between job satisfaction, sense of efficacy, and teachers' extra-role behavior. Teaching and Teacher Education, 16(5), 649-659. Retrieved from https://doi.org/10.1016/s0742-051x(00)00012-3

Stearns, E., Banerjee, N., Mickelson, R. \& Moller, S. (2014). Collective pedagogical teacher culture, teacher-student ethno-racial mismatch, and teacher job satisfaction. Social Science Research, 45, 56-72. Retrieved from https://doi.org/10.1016/j.ssresearch.2013.12.011

Stoll, L. (1999). School culture: Black hole or fertile garden for school improvement? In: Prosser, J. (ed.), School Culture. London, Paul Chapman (pp. 60-76). Retrieved from https://doi.org/10.4135/9781446219362.n3

Treputtharat, S. \& Tayiam, S. (2014). School climate affecting job satisfaction of teachers in primary education, Khon Kaen, Thailand. Procedia-Social and Behavioral Sciences, 116, 996-1000. Retrieved from https://doi.org/10.1016/j.sbspro.2014.01.334

Usop, A. M., Kadtong, M. L. \& Usop, D. A. S. O. (2013). The significant relationship between work performance and job satisfaction in Philippines. International Journal of Human Resource Management and Research, 3(2), 9-16.

Vadi, M. (2007). Relationships between organizational culture and performance in Estonian schools with regard to their size and location. Baltic Journal of Economics, 1, 3-17. Retrieved from https://doi.org/10.1080/1406099x.2007.10840438

Zhu, C., Devos, G. \& Tondeur, J. (2014). Examining school culture in Flemish and Chinese primary schools. Educational Management Administration \& Leadership, 42(4), 557-575. Retrieved from https://doi.org/10.1177/1741143213502190 